\title{
Using Molecular Biology Tools to Identify Abscission Materials for Citrus
}

\author{
Jacqueline K. Burns ${ }^{1}$ \\ University of Florida, Citrus Research and Education Center, 700 Experiment Station Road, \\ Lake Alfred, FL 33850-2229
}

A fundamental element of plant development is abscission of mature or ripe fruit, senescent tissues, or damaged organs. Abscission is a complex, organized, and regulated process that occurs in predetermined and defined areas in plants called abscission zones. During abscission, cytoplasmically dense cells, located in abscission zones of plants, undergo division and elongation, followed by increased gene expression and activity of enzymes involved in cell wall modification, such as cellulase, polygalacturonase, and pectinesterase (Roberts et al., 2000). These events have been documented in citrus fruit and leaves (Burns and Lewandowski, 2000; Burns et al., 1998; Goren, 1993; Kazokas and Burns, 1998). The cell wall hydrolases are believed to degrade the middle lamella of adjoining cells in the abscission zone, greatly weakening the bond between organ and parent plant. Cells that line the developing fracture plane eventually differentiate into peridermal scar tissue (Bleecker and Patterson, 1997) and, as such, form a barrier to desiccation and pathogen attack.

The plant hormones ethylene and auxin affect abscission. Ethylene promotes abscission, whereas auxin is thought to delay the process (Brown, 1997). Abscission in citrus fruit and leaves can be impeded by the use of ethylene action inhibitors, such as silver thiosulfate (STS) or 1-methylcyclopropene (1-MCP; Pozo and Burns, unpublished data). Ethylene action inhibitors block the binding of ethylene to ethylene receptor(s) located within in the plant and thereby prevent downstream events that lead to abscission or other ethylene-related responses. Ethylene perception is thought to be controlled by a family of five genes in Arabidopsis. Two of these genes, ETRI and ERS1, encode proteins similar to "two-component receptor systems" and contain an ethylene-binding site within their membrane-spanning domains (Bleecker and Kende, 2000; Hall et al., 2000). Although similar in many respects, notable differences in predicted structure, affinities for downstream interaction with CTR1, and ethylene inducibility of ETR1 and ERS1 transcripts suggest that differential responses to ethylene could be related to the presence or expression of ETR1 and/or ERS1 genes in tissues.

During the course of development, plants often shed leaves, fruit, and flowers independently. This suggests that mechanisms exist to preferentially abscise mature fruit without affecting leaves, flowers, or developing fruit. Two major objectives of our abscission research program at the Citrus Research and Education Center in Lake Alfred are to: 1) define changes that occur during the abscission process in citrus fruit and leaves and 2) translate this information into viable abscission agents for the Florida citrus industry. Currently, there are no registered abscission materials that can be used for citrus in the United States. A number of abscission materials have been tested in several citrus fruit-producing countries over several decades. From these materials, Ethrel ${ }^{\circledR}$ (2-chloroethyl phosphonic acid) and 5-chloro-3methyl-4-nitro-1 $H$-pyrazole (CMN-P, formerly known as "Release") emerged as effective fruit looseners for citrus.

After application to plant surfaces, Ethrel ${ }^{\circledR}$ is transported into the more alkaline intracellular compartments and, as a result, releases ethylene (Cookle and Randall, 1968). Ethrel ${ }^{\circledR}$ has been useful as an abscission aid for harvesting plums, cherries (Bukovac et al., 1969; Flore and Bukovac, 1982), and olives (Martin et al., 1981). However, at the higher concentrations often necessary to elicit a desirable effect

Received for publication 29 Nov. 2001. Accepted for publication 30 Nov. 2001. This research was supported by the Florida Agricultural Experiment Station, and approved for publication as Journal Series No. R-08293. I gratefully acknowledge support by the Florida Dept. of Citrus and the Univ. of Florida for this work.

${ }^{1}$ Professor. on mature fruit abscission in citrus and cherry, Ethre ${ }^{\circledR}$ can cause excessive leaf abscission and gummosis (Bukovac et al., 1969; Pozo and Burns, unpublished data). In contrast, CMN-P at low concentrations is a very effective abscission material for citrus because it rapidly elicits mature fruit abscission without causing defoliation, immature fruit drop, or floral abscission (Hartmond et al., 2000b). We used Ethre ${ }^{\circledR}$ and CMN-P to cause abscission in 'Valencia' and searched for unique gene expression induced by these compounds. In this communication, results are presented on induction and characterization of abscission-related genes $48 \mathrm{~h}$ after application of abscission materials. Data are presented that demonstrate the use of such information to select abscission materials for citrus.

\section{MATERIALS AND METHODS}

Plant material for RNA isolation. In 1999, 2000, and 2001, fieldgrown 12- and 13-year-old 'Valencia' trees located at the Citrus Research and Education Center, Lake Alfred, Fla., were sprayed with $200 \mathrm{mg} \cdot \mathrm{L}^{-1} \mathrm{CMN}-\mathrm{P}$ or Ethrel ${ }^{\circledR}$. Abscission material solutions contained $0.125 \%$ Kinetic as adjuvant. Control trees were sprayed with adjuvant alone. Each tree received $\approx 5 \mathrm{~L}$ of solution directed at the canopy. Ten trees were used per treatment each year. Representative fruit with subtending stems and small branches containing leaves were harvested from trees $0,6,24$, and $48 \mathrm{~h}$ after treatment application. Fruit abscission zone tissue was removed using a sharpened 4-mm-diameter cork borer. The borer was slipped over the pedicel and pushed through the calyx and fruit peel. The location of the fruit abscission zone was visually determined in this tissue cylinder and further trimmed to $6 \mathrm{~mm}$ $\times 4 \mathrm{~mm}$. For leaf abscission zones, $4 \mathrm{~mm}$ of tissue, containing the laminar abscission zone located at the petiole/blade junction, was excised. Leaf blade tissue was excised from mid-blade and did not include midrib tissues. Mature and immature fruit and leaf abscission zone and leaf blade tissues were frozen in liquid nitrogen and stored at $-80{ }^{\circ} \mathrm{C}$. When needed, tissues were ground to a fine powder for RNA extraction.

Plant material and methods for screening putative abscission materials. Field-grown 'Valencia' trees or 3-year-old potted calamondin trees in the greenhouse were used to screen putative abscission materials. Whole-tree canopies, individual branches, or, alternatively, direct mature fruit abscission zone treatments were used to apply test substances. About $5 \mathrm{~L}$ or $500 \mathrm{~mL}$ of solution containing test substances plus adjuvant was applied to whole tree canopies of 'Valencia' or calamondin, respectively, whereas $100 \mathrm{~mL}$ was applied to 'Valencia' branches. Branch tests were applied to runoff. For direct abscission zone applications, $500 \mu \mathrm{L}$ of solution containing test substances plus adjuvant was applied to absorbent cotton swabs affixed to the pedicle/ fruit junction near the calyx abscission zone. Cotton swabs containing test substances were dry generally within an hour after application. Fruit detachment force (FDF) was measured in mature 'Valencia' and calamondin fruit by using a digital force gauge (Force Five, Wagner Instruments, Greenwich, Conn.). Fruit were harvested in the field with $15-20 \mathrm{~cm}$ attached stems and transported to the laboratory. Stems were clipped to $\approx 2.5 \mathrm{~cm}$, inserted into the gauge, and the stem pulled parallel to the fruit axis until it separated from the fruit. FDF was measured in Newtons (N). Percent fruit or leaf drop was determined by counting the number of fruit or leaves on the ground and dividing by the total number of fruit or leaves.

RNA isolation, differential display, and construction of subtraction libraries. Total RNA was extracted using standard procedures (Burns et al., 1998) or the RNeasy Plant Mini Kit according to the manufacturer's specifications (Qiagen, San Francisco). Total RNA 
was used as template for the reverse transcriptase reaction followed by differential display PCR (polymerase chain reaction) with $\left[\alpha-{ }^{33} \mathrm{P}\right]$ dATP. Random-arbitrary and anchored primers were purchased from Operon Technologies (Alameda, Calif.) and Clontech Laboratories (Palo Alto, Calif.). PCR-amplified cDNA fragments were separated on denaturing $5 \%$ polyacrylamide gels in TRIS-borate electrophoresis (TBE) buffer. cDNAs were isolated from dried gels, re-amplified by PCR, and cloned as described (Ohet al., 1995). Total RNA extracted from mature 'Valencia' fruit abscission zones $48 \mathrm{~h}$ after CMN-P and adjuvant alone treatment applications were used to construct the subtraction library. Library subtractions were performed using PCRSelect cDNA Subtraction Kit from Clontech Laboratories, as described in the manufacturer's specifications.

DNA sequencing, homology searches, PCR, and northern blotting. Nucleotide sequencing was provided by the DNA Sequencing Core Facility (Univ. of Florida, Gainesville). Nucleotide and amino acid sequence analysis as well as multiple sequence alignment were performed with OMIGA 2.0 software (Accelrys, San Diego). For homology search, cDNA sequences were compared to the NCBI (National Center for Biotechnology Information) non-redundant databases. Initial verification of differential expression was accomplished using reverse transcription (RT)-PCR. Differentially expressed sequences verified by PCR were used as probes for northern hybridization. For northern blotting, total RNA $(10 \mu \mathrm{g} / \mathrm{lane})$ from each plant tissue was loaded and separated on $1.2 \%$ formaldehyde denaturing agarose gels. RNA was transferred overnight onto neutral nylon membranes (Hybond-N; Amersham, Piscataway, N.J.) using a TURBOBLOTTER (Schleicher \& Schuell, Keene, N.H.). Radiolabeled probes were prepared with $\left[\alpha_{-}{ }^{32} \mathrm{P}\right] \mathrm{dCTP}$ (NEN Life Science Products, Boston) using a random primer-labeling kit (Gibco BRL, Rockville, Md.). RNA membranes were pre-hybridized and hybridized in PerfectHyb Plus Hybridization Buffer (Sigma, St. Louis) according to manufacturer's instruction.
Compounds used to alter abscission. Pseudomonas syringae pv. glycinea strain PG4180.N9 was provided by Dr. Carol Bender, Oklahoma State Univ. Coronatine was produced by fermentation with $P$. syringae and isolated according to established procedures (Palmer and Bender, 1993). Applications of coronatine were made to canopies of citrus at $200 \mathrm{mg} \cdot \mathrm{L}^{-1}$ at $\approx 5 \mathrm{~L} /$ tree. Adjuvant was added to coronatine solutions as described above. Guanfacine and clonidine were purchased from Tocris (Ellisville, Mo.) and Sigma, respectively. Compounds ( 1 or $2 \mathrm{~mm}$ ) were dissolved in Ethrel solutions containing adjuvant and applied immediately to canopies of citrus. Solution $\mathrm{pH}$ remained between 5 and 6. Metsulfuron-methyl (Ally; DuPont Chemical Co., Wilmington, Del.) was purchased from Helena Chemical Co. (Collierville, Tenn.) and applied as described (Kender et al., 1999). Methyl jasmonate was purchased from Bedoukian Research (Danbury, Conn.) and applied as described (Hartmond et al., 2000a).

\section{RESULTS AND DISCUSSION}

An effective abscission material for Florida citrus must favorably enhance fruit removal with no undesirable effects on leaf abscission, next year's yield, and tree health. Throughout the 'Hamlin' and 'Valencia' harvest season in Florida, periods of shoot growth alternate with periods of root growth (Fig.1). During the 'Valencia' harvest season, mature fruit, flowers, leaves, young shoots, and young developing fruit can be on the tree simultaneously. Selectivity is a particularly challenging issue when searching for an effective abscission material, especially for 'Valencia'.

In screening work with putative abscission materials, we often use calamondin trees in preliminary trials, especially in the summer and early fall months when mature fruit on commercial cultivars are not available. When screening putative abscission materials, whole tree applications are preferred; however, in situations where limited materials are available, branch tests or direct abscission zone applications

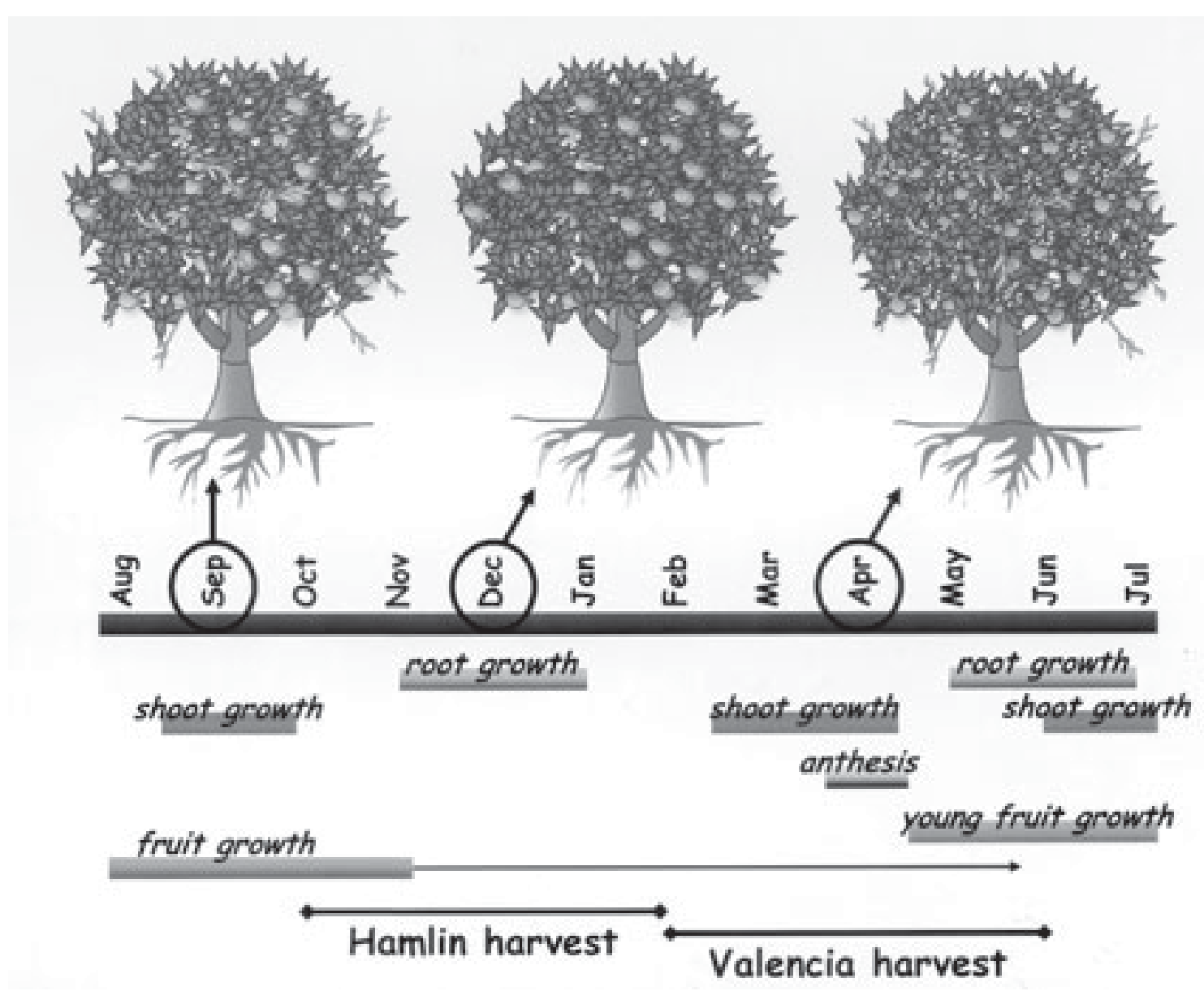

Fig. 1. Schematic representation of yearly vegetative and reproductive growth and development of Florida citrus. Typical harvest times throughout the season for 'Hamlin' and 'Valencia' are depicted. 
are used. Calamondin has proven to be an excellent model system for screening compounds (Wilson et al., 1977) because it has three or more crops of fruit throughout a year and its response to abscission materials is similar to commercial citrus cultivars. However, there are notable differences in response that must be considered when using calamondin. In our experience, calamondin is less sensitive to Ethrel ${ }^{\circledR}$ than commercial citrus cultivars. We typically use $400 \mathrm{mg} \cdot \mathrm{L}^{-1}$ Ethrel ${ }^{\circledR}$ in calamondin to reduce FDF to $50 \%$ of the original value, whereas a $50 \%$ reduction in FDF is typically achieved with $200 \mathrm{mg} \cdot \mathrm{L}^{-1}$ in commercial cultivars under Florida conditions.

Application of $200 \mathrm{mg} \cdot \mathrm{L}^{-1}$ Ethrel ${ }^{\circledR}$ or CMN-P to 'Valencia' orange trees resulted in a reduction in FDF $24 \mathrm{~h}$ after treatment (Fig. 2). FDF continued to decline $24 \mathrm{~h}$ after trees were treated with $200 \mathrm{mg} \cdot \mathrm{L}^{-1}$ CMN-P, but not with Ethrel®. Leaf drop is generally unaffected by CMN-P treatment at recommended rates, but is promoted with Ethrel ${ }^{\circledR}$ treatment, especially during high temperatures (data not shown). Differences in leaf drop between CMN-P and Ethrel ${ }^{\circledR}$ treatments in potted calamondin trees are illustrated in Fig. 3. Leaf drop was low at 0 to $1000 \mathrm{mg} \cdot \mathrm{L}^{-1} \mathrm{CMN}-\mathrm{P}$, but markedly increased at concentrations of 2000 to $3500 \mathrm{mg} \cdot \mathrm{L}^{-1}$. Ethrel ${ }^{\circledR}$ induced significant leaf drop with concentrations greater than $200 \mathrm{mg} \cdot \mathrm{L}^{-1}$. FDF was similarly reduced in calamondin trees treated with $200 \mathrm{mg} \cdot \mathrm{L}^{-1} \mathrm{CMN}-\mathrm{P}$ or $400 \mathrm{mg} \cdot \mathrm{L}^{-1}$ Ethrel ${ }^{\circledR}$ applications (data not shown).

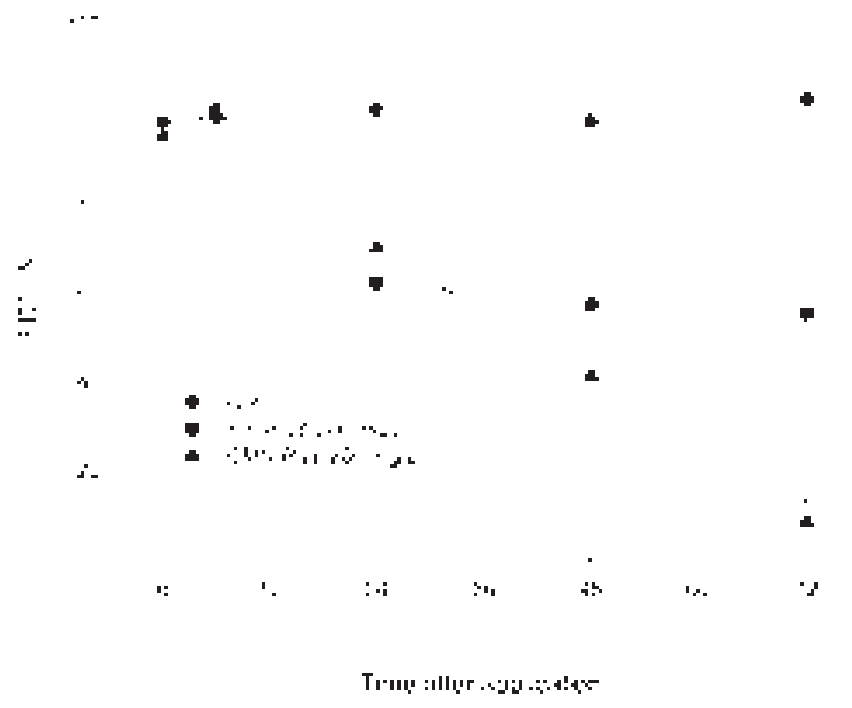

Fig. 2. The effect of CMN-P and Ethrel® on reduction of FDF in 'Valencia' orange from 0 to $72 \mathrm{~h}$ after abscission material application. SE is indicated.

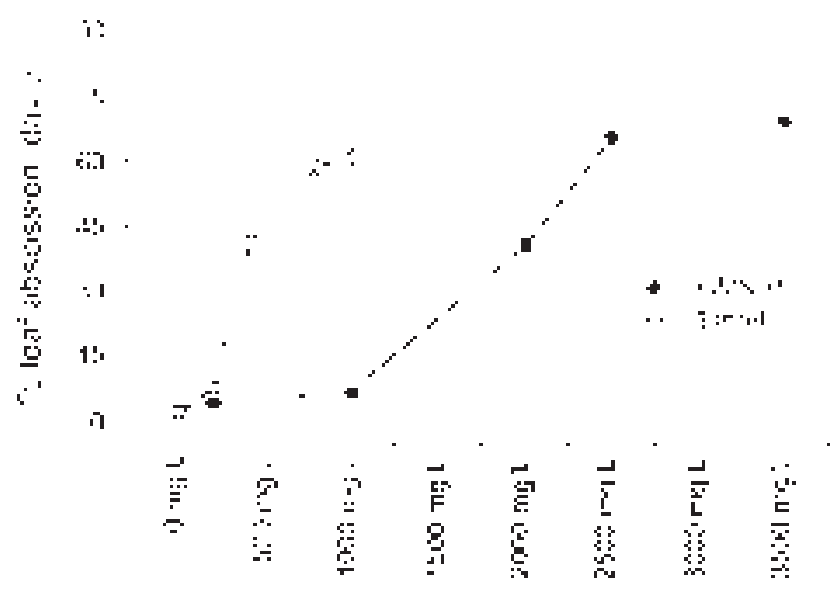

\section{contentration}

Fig. 3. Leaf abscission induced by increasing concentrations of Ethrel® or CMN-P in calamondin $5 \mathrm{~d}$ after application. SE is indicated.
Differential mRNA display and subtractive cDNA library screening was used to search for unique abscission-related metabolism that could be targeted in a strategy to alter abscission in commercial cultivars of citrus. Our initial search focused on unique genes expressed $48 \mathrm{~h}$ after CMN-P and/or Ethrel ${ }^{\circledR}$ application in 'Valencia'. We sequenced over 200 subtracted cDNA clones and $120 \mathrm{cDNA}$ clones obtained by differential display. Differential expression of some of these genes was confirmed by northern hybridization and/or RT-PCR. The identities of subtracted and differentially displayed cDNAs enabled us to evaluate metabolic pathways affected by abscission. Isolated cDNAs obtained from our gene-hunting strategy encoded proteins that were either up-regulated in response to CMN-P in abscission zones and other non-abscising tissues, down-regulated in non-abscising tissues but up-regulated in mature fruit abscission zones, or up-regulated in mature fruit abscission zones. In general, isolated cDNAs encoded proteins that could be grouped into three areas of metabolism: 1) hormonal regulation/signal transduction, 2) cell wall metabolism, and 3) secondary metabolism/PR proteins. Table 1 gives examples of encoded proteins derived from cDNAs found to be up-regulated during the abscission process in citrus.

Compounds that alter abscission response were selected for screening based on cDNA identities and putative affected metabolism. For example, cDNAs encoding proteins involved in jasmonic acid biosynthesis were present in cDNA subtraction libraries that represented genes differentially present in mature fruit abscission zones treated with CMN-P. These up-regulated genes included allene oxide synthase and 12-oxophytodienoate reductase (Table 1). Jasmonic acid and its methyl ester methyl jasmonate are octadecanoids known to induce a variety of plant responses related to defense (Rickauer et al., 1997), wounding (Lee et al., 1998), fruit ripening (Fan et al., 1998), and secondary metabolite synthesis (Memelink et al., 2001). Jasmonic acid was also shown to promote bean leaf abscission (Ueda et al., 1996). Methyl jasmonate promoted mature fruit drop and ethylene production in citrus (Hartmond et al., 2000a; Kender et al., 2001). Unfortunately, leaf drop was excessive at concentrations necessary to cause fruit loosening. Alternative compounds were sought that would mimic the effect of jasmonates on fruit loosening but with less effect on leaf abscission.

An example of such a compound selected as an abscission agent, using information from the gene expression work, is coronatine. Coronatine is a fermentation product of several pathovars of Pseudomonas syringae and has similar biological activities to methyl jasmonate

Table 1. Proteins encoded by cDNAs identified by differential mRNA display or subtractive cDNA library screening. Up-regulation was confirmed by northern hybridization and/or RT-PCR. Numbers in parenthesis indicate number of isolated genes encoding the same protein but with different nucleotide and amino acid sequence. In addition to the cDNAs listed below, two cDNAs were identified that had open reading frames encoding proteins with significant matches to arabidopsis protein sequences with no known function.

\begin{tabular}{|c|c|}
\hline $\begin{array}{l}\text { Hormonal metabolism/signal } \\
\text { transduction }\end{array}$ & Secondary metabolism/PR protein \\
\hline $\begin{array}{l}\text { ACC oxidase } \\
\text { IAA amino acid hydrolase } \\
\text { IAA-induced gh3 } \\
\text { IAA glucosyltransferase } \\
\text { ubiquitin-conjugating protein } \\
\text { serine/threonine kinase (3) } \\
\text { 12-oxophytodienoate reductase } \\
\text { allene oxide synthase }\end{array}$ & $\begin{array}{l}\text { 1,4-benzoquinone reductase } \\
\text { caffeic acid } O \text {-methyltransferase } \\
\text { chitinase } \\
\text { cinnamic acid 4-hydroxylase } \\
\text { 7-ethoxycoumarin } O \text {-deethylase } \\
\text { phenylalanine ammonia lyase } \\
\text { protein inhibitor, pinII } \\
\text { PR protein, class } 4(2) \\
\text { UDP-galacturonosyl transferase } \\
\text { amine oxidase } \\
\text { catalase } \\
\text { disease-related protein (2) }\end{array}$ \\
\hline \multicolumn{2}{|c|}{ Cell wall modification } \\
\hline $\begin{array}{l}\text { acidic cellulase cel-a1 } \\
\text { basic cellulase cel-b1 } \\
\text { expansin } \\
\beta \text {-galactosidase }\end{array}$ & $\begin{array}{l}\text {-1,3-glucanase } \\
\text { lipid transfer protein } \\
\text { pectinesterase } \text { cspme3 } \\
\text { polygalacturonase (3) }\end{array}$ \\
\hline
\end{tabular}


(Bender 1999; Koda et al., 1995). Application of coronatine to plant tissues causes ethylene production (Ferguson and Mitchell, 1985; Kenyon and Turner, 1992; Perner et al., 1994). A $200 \mathrm{mg} \cdot \mathrm{L}^{-1}$ solution of coronatine was applied to 'Valencia' and compared with $200 \mathrm{mg} \cdot \mathrm{L}$ ' ${ }^{1} \mathrm{CMN}-\mathrm{P}$ and $200 \mathrm{mg} \cdot \mathrm{L}^{-1} \mathrm{Ethrel} \AA$. Five days after application, reduction in FDF induced by coronatine was equal to or greater than that induced by CMN-P (Fig. 4). Leaf abscission was high in Ethrel®treated trees but $<20 \%$ in coronatine-treated trees. It is unclear what affect this level of defoliation would have on long term tree health and return yield, especially under conditions of annual defoliations that would be expected with commercial abscission material applications. In contrast to coronatine treatments, leaf abscission was $<3 \%$ in trees sprayed with CMN-P or adjuvant alone.

Several cDNAs were isolated that encoded proteins involved in IAA metabolism (Table 1). IAA is known to alter the sensitivity of tissues to ethylene, and exogenous applications delay abscission (Brown, 1997). cDNAs encoding proteins involved in inputs to the IAA pool (IAA amino acid hydrolase; Bartel and Fink, 1995), inputs and outputs to the IAA pool (IAA glucosyltransferase; Szerszen et al. 1994), and those induced by auxin (IAA-induced gh3; Hagen et al., 1984) were isolated, suggesting the complex manner in which auxins participate in the abscission process. In a straightforward way, leaves often do not abscise, even though adjacent mature fruit mature, evolve ethylene, ripen and abscise. This suggests a mechanism exists that enables preferential abscission of organs throughout a plant's lifetime. Differences in ethylene perception within different tissues and developmental stages could play a role in preferential abscission, and this could be related to auxin.

Ethrel applications to Florida citrus that result in good fruit loosening cause high levels of defoliation. Several auxins such as 2,4dichlorophenoxyacetic acid, naphthaleneacetic acid and 2,4,5-
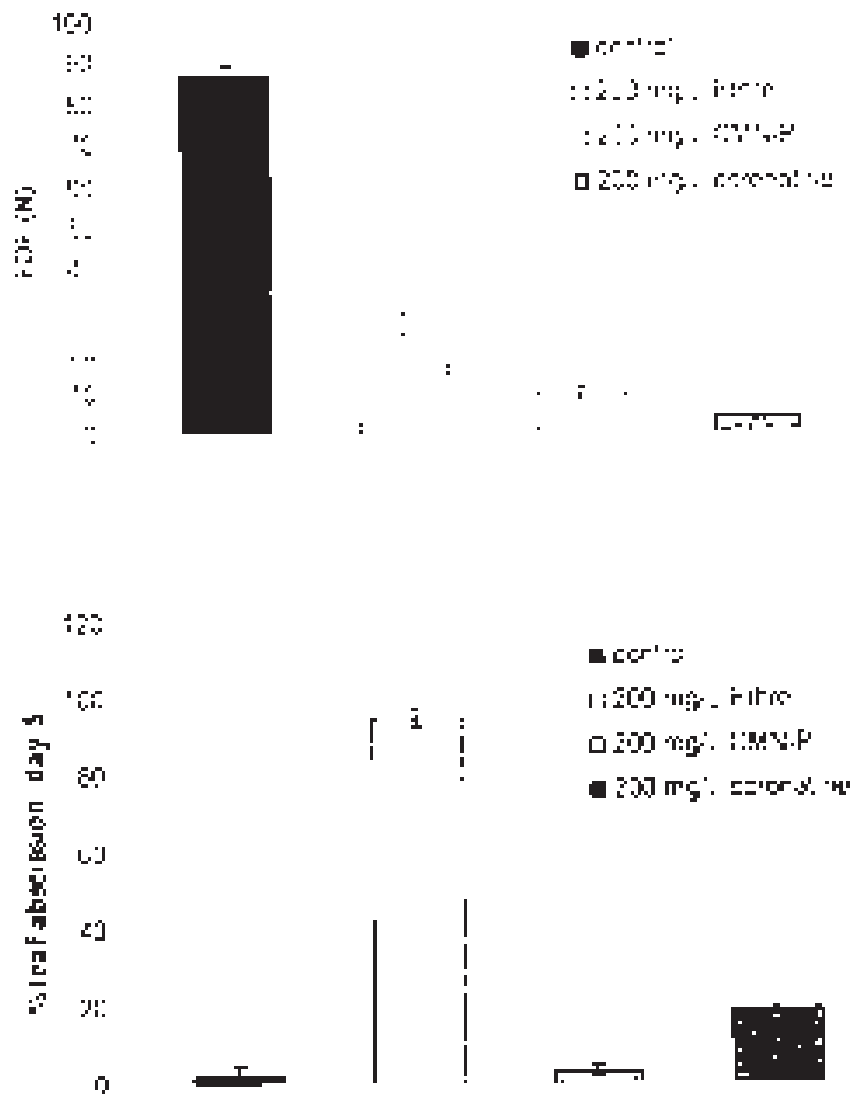

Fig. 4. Fruit detachment force (FDF, top panel) and percent leaf abscission (bottom panel) associated with Ethrel®, CMN-P, and coronatine application in 'Valencia' orange. Data are means of FDF and percent leaf abscission $5 \mathrm{~d}$ after application. SE is indicated. trichlorophenoxyacetic acid were applied to citrus canopies either before or during Ethrel applications to determine if leaf loss could be controlled while still enabling fruit loosening. Predictably, these auxins inhibited both leaf loss and fruit loosening. At low dosages, preferential mature fruit abscission was not achieved (data not shown). Other compounds were sought with altered structures that could have auxin activity. Upon further study of the gene expression information, a series of compounds was selected that reduced defoliation associated with Ethrel application. Clonidine and guanfacine are examples of compounds in this series (Fig. 5). These compounds are known in mammalian research as $\alpha_{2}$-adrenergic receptor agonists, and function by influencing calcium influx and signal transduction in pre- and postsynaptic neurons (Feldman et al., 1997). The structure of both compounds have some similarity with auxins of the benzoic acid and phenoxyacetic acid series, but with notable differences. For example, the compounds are basic and do not contain a carboxylic acid function, and the ether function indicative of the phenoxyacetic acid series is absent.

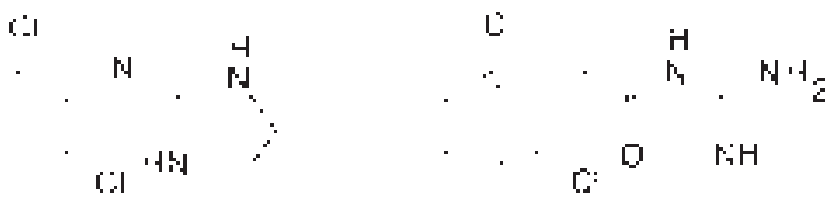

\section{clonidine guanfacine}

Fig. 5. Chemical structures of clonidine and guanfacine.
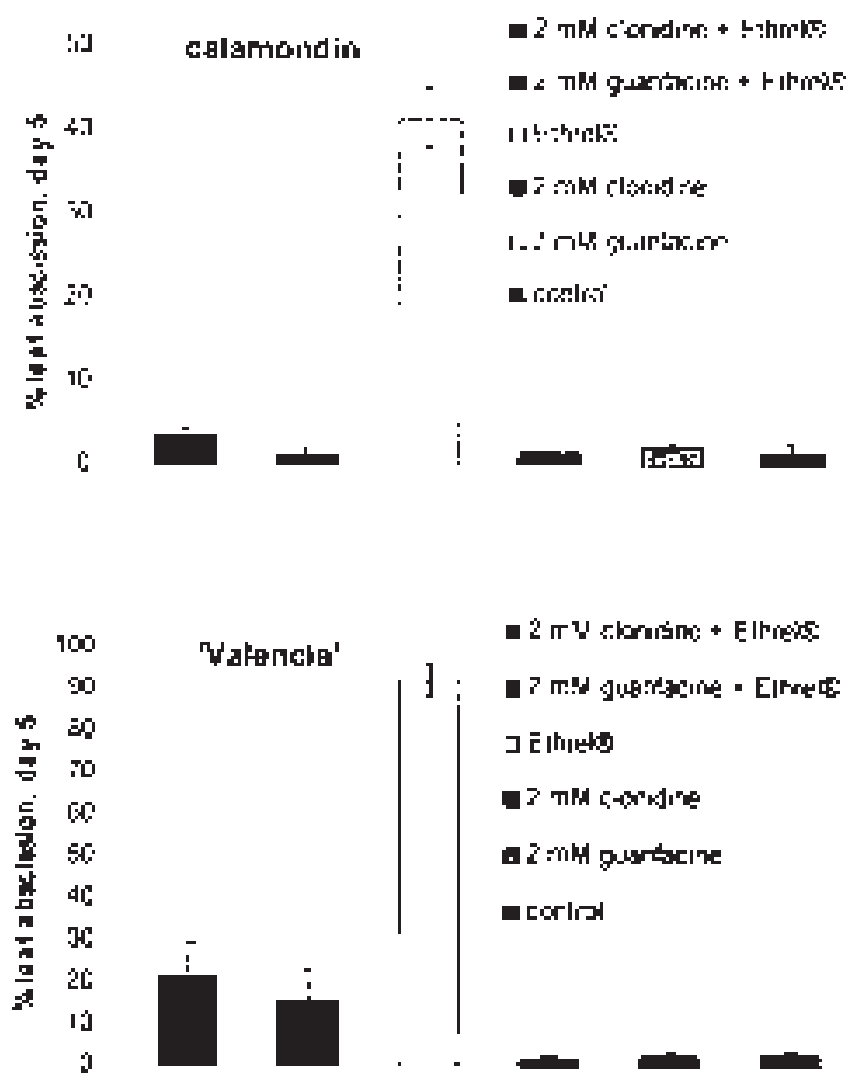

Fig. 6. Reduction in percent leaf abscission in calamondin (top panel) and 'Valencia' (bottom panel) trees treated with clonidine or guanfacine in combination with Ethrel@. Calamondin was treated with $400 \mathrm{mg} \cdot \mathrm{L}^{-1}$ Ethrel ${ }^{\circledR}$, whereas 'Valencia' was treated with $200 \mathrm{mg} \cdot \mathrm{L}^{-1}$ Ethrel ${ }^{\circledR}$. Data are means of percent leaf abscission $5 \mathrm{~d}$ after application. SE is indicated. 
A 200 or $400 \mathrm{mg} \cdot \mathrm{L}^{-1}$ solution of Ethrel ${ }^{\circledR}$ containing $2 \mathrm{~mm}$ clonidine or guanfacine was applied to 'Valencia' and calamondin trees, respectively. Combining these compounds in the spray mixture with Ethrel ${ }^{\circledR}$ reduced defoliation associated with abscission material application in both citrus types (Fig. 6). Interestingly, these same combination treatments did not significantly impair the ability of Ethrel ${ }^{\circledR}$ to reduce FDF (Fig. 7). This suggests that these compounds alter sensitivity of leaves to abscission materials, leading to leaf retention while not affecting the ability of fruit to respond.

The mode of action of guanfacine and clonidine in plants is unknown but will be the subject of future research. Application of these compounds to cuttings of coleus and tomato promoted lateral root formation (data not shown), indicating that these compounds may have auxin-like activity. Similarly, the reason for the preferential inhibition of leaf abscission in guanfacine- and clonidine-treated plants is also unknown. It is worth noting that the side chains of both compounds contain an a guanidine-related moiety. Some guanidinerelated compounds are potent inhibitors of inducible nitric oxide synthases (Griffiths et al., 1993; Southan et al., 1995).

Other abscission materials were combined with clonidine to determine if defoliation could be reduced. We previously reported that acetolactate synthase inhibitors such as metsulfuron-methyl and prosulfuron (Burns et al., 1999; Kender et. al., 1999) induced abscission in citrus, but defoliation and twig-dieback were serious side effects. Methyl jasmonate was also identified as a good citrus fruit abscission agent, but significant defoliation at effective fruit loosening concentrations occurred (Hartmond et al., 2000a). Combining metsulfuronmethyl or methyl jasmonate with clonidine reduced defoliation associated with abscission material application (Fig. 8) and greatly reduced or eliminated twig-dieback in calamondin trees sprayed with metsulfuron-methyl (data not shown). Taken together, these data suggest that clonidine and guanfacine could be used to reduce defoliation associated with LA-503 treatment. Studies to address this are now under way.

Future work will focus on identification of unique abscissionrelated events induced early in the abscission process. "Profiling" affected metabolism at these early time points will enable us to identify additional compounds that may be useful for citrus abscission.

\section{Literature Cited}

Bartel, B., and G.R. Fink. 1995. ILR1, an amidohydrolase that releases active auxin indole-3-acetic acid from conjugates. Science 268:1745-1748.

Bender, C.L. 1999. Chlorosis-inducing phytotoxins produced by Pseudomonas syringae. Eur. J. Plant Pathol. 105:1-12.

Bleecker, A.B. and H. Kende. 2000. Ethylene: A gaseous signal molecule in plants. Annu. Rev. Cell Dev. Biol. 16:1-18.

Bleecker, A.B. and S.E. Patterson. 1997. Last exit: Senescence, abscission and meristem arrest in Arabidopsis. Plant Cell 9:1169-1179.

Brown, K.M. 1997. Ethylene and abscission. Physiol. Plant. 100:567-576.

Bukovac, M.J., F. Zucconi, R.P. Larsen, and C.D. Kesner. 1969. Chemical promotion of fruit abscission in cherries and plums with special reference to 2-chloroethylphosphonic acid. J.Amer. Soc. Hort. Sci. 94:226-230.

Burns, J.K., U. Hartmond, and W.J. Kender. 1999. Acetolactate synthase inhibitors increase ethylene production and cause fruit drop in citrus. HortScience 34:908-910.

Burns, J.K. and D.J. Lewandowski. 2000. Genetics and expression of pectinmethylesterase, endo- $\beta$-glucanase and polygalacturonase genes in Valencia orange. Acta Hort. 535:65-80.

Burns, J.K., C.J. Nairn, D.J. Lewandowski, and G.E. Brown. 1998. Endo-B-1,4glucanase gene expression and cell wall hydrolase activities during abscission of 'Valencia' orange. Physiol. Plant. 102:217-225.

Cookle, A.R. and D.I. Randall. 1968. 2-Haloethanephosphonic acids as ethylene releasing agents for induction of flowering in pineapples. Nature 218:974-975.

Fan, X., J.P. Mattheis, and J.K. Fellman. 1998. A role of jasmonates in climacteric fruit ripening. Planta 204:444-449.

Feldman, R.S., J.S. Meyer, and L.F. Quenzer. 1997. In 'Principles of Neuropsychopharmacology', Sinauer Assoc., Sunderland, Mass., Chapter 8, p. 277-344.

Ferguson, I.B., and R.E. Mitchell. 1985. Stimulation of ethylene production in bean leaf discs by the Pseudomonad phytotoxin coronatine. Plant Physiol. 77:969-973.

Flore, J.A. and M.J. Bukovac. 1982. Factors influencing absorption of ${ }^{14} \mathrm{C}(2-$

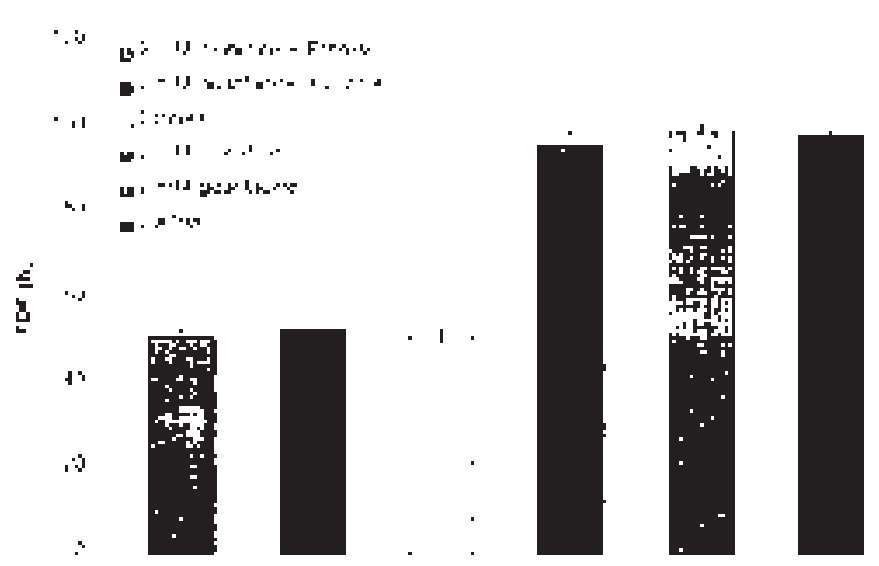

Fig. 7. Fruit detachment force (FDF) of fruit of 'Valencia' trees treated with clonidine or guanfacine in combination with Ethrel $^{\circledR}$. Data are means of FDF $5 \mathrm{~d}$ after application. SE is indicated.

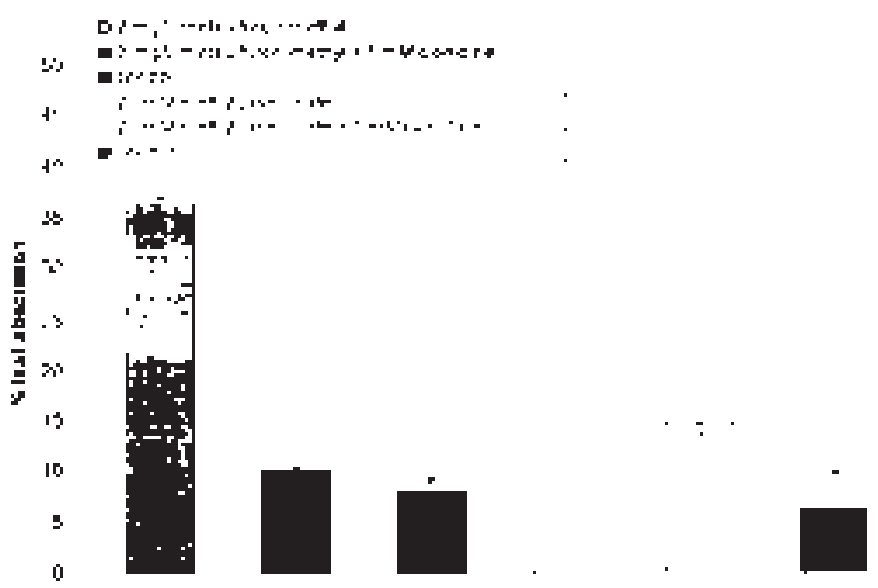

Fig. 8. The effect of clonidine on percent leaf abscission associated with metsulfuron-methyl (left panel) or methyl jasmonate (right panel) application in calamondin. Data for metsulfuron-methyl leaf abscission were collected $27 \mathrm{~d}$ after application, whereas data for methyl jasmonate were collected $5 \mathrm{~d}$ after application. SE is indicated.

chloroethyl-phosphonic acid by leaves of cherry. J. Amer. Soc. Hort. Sci. 107:965-968.

Goren, R. 1993. Anatomical, physiological and hormonal aspects of abscission in citrus. Hort. Rev. 15:145-182.

Griffiths, M.J., M. Messent, R.J. MacAllister, and T.W. Evans. 1993. Aminoguanidine selectively inhibits inducible nitric oxide synthase. Br. J. Pharmacol. 110:963-968.

Hagen, G., A. Kleinschmidt, and T. Guilfoyle. 1984. Auxin-regulated gene expression in intact soybean hypocotyl and excised hypocotyl sections. Planta 162:147-153.

Hall, A.E., J.L. Findell, G.E. Schaller, E.C. Schaller, E.C. Sisler, and A.B. Bleeker. 2000. Ethylene perception by the ERS1 protein in Arabidopsis. Plant Physiol. 123:1449-1457.

Hartmond, U., R. Yuan, J.K. Burns, A. Grant, and W.J. Kender. 2000a. Citrus fruit abscission induced by methyl jasmonate. J. Amer. Soc. Hort. Sci. 125:547-552.

Hartmond, U., J.D. Whitney, J.K. Burns, and W.J. Kender. 2000b. Seasonal variation in the response of 'Valencia' orange to two abscission compounds. HortScience 35:226-229.

Kazokas, W.C. and J.K. Burns. 1998. Cellulase activity and gene expression in citrus fruit abscission zones during and after ethylene treatment. J. Amer. Soc. Hort. Sci. 123:781-786.

Kender, W.J., U. Hartmond, and J.K. Burns. 1999. Fruit abscission and leaf drop in citrus cultivars treated with metsulfuron-methyl. HortTechnology 9:412-416.

Kender, W.J., U. Hartmond, J.K. Burns, R. Yuan, and L. Pozo. 2001. Methyl jasmonate and $\mathrm{CMN}$-pyrazole applied alone and in combination can cause mature orange abscission. Sci. Hort. 88:107-120. 
Kenyan, J.S. and J.G. Turner. 1992. The stimulation of ethylene synthesis in Nicotiana tabacum leaves by the phytotoxin coronatine. Plant Physiol. 100:219-224.

Kodo, Y., K. Takahashi, Y. Kikuta, F. Greulich, H. Toshima, and A. Ichihara. 1995. Similarities of the biological activities of coronatine and coronafacic acid to those of jasmonic acid. Phytochem. 41:93-96.

Lee, S.H., M.H. Lee, W.I. Chung, and J.R. Liu. 1998. WAPK, a ser/thr protein kinase genes of Nicotiana tabacum, is uniquely regulated by wounding, abscisic acid and wounding. Mol. Gen. Genet. 259:516-522.

Martin, G.C., S. Lavee, and G.S. Sibbett. 1981. Chemical loosening agents to assist mechanical harvest of olive. J. Amer. Soc. Hort. Sci. 106:325-330.

Memelink, J., R. Verpoorte, and J.W. Kijne. 2001. ORCAnization of jasmonateresponsive gene expression in alkaloid metabolism. Trends Plant Sci. 6:212-219.

Oh, B.J, D.E. Balint, and J.J. Giovannoni. 1995. A modified procedure for PCR-based differential display and demonstration of use in plants for isolation of gene related to fruit ripening. Plant Mol. Biol. Rep. 13:70-81.

Palmer, D.A., and C.L. Bender. 1993. Effects of environmental and nutritional factors on production of the polyketide phytotoxin coroantine by Pseudomonas syringae pv. glycinea. Appl. Environ. Microbiol. 59:1619-1626.

Perner, B., H.P. Schmauder, J. Müller, F. Greulich, and F. Bublitz. 1994. Effect of coronatine on ethylene release and ATPase activity of tomato cell cultures. J. Phytopath. 142:27-36.

Rickauer, M., W. Brodschelm, A. Bottin, C. Veronesi, H. Grimal, and M. T. Esquerre-Tugaye. 1997. The jasmonate pathway is involved differentially in the regulation of different defense responses in tobacco cells. Planta 202:155-162.

Roberts, J.A., C.A. Whitelaw, Z.H. Gonzalez-Carranza, and M.T. McManus. 2000. Cell separation processes in plants-Models, mechanisms and manipultion. Ann. Bot. 86:223-235.

Southan, G.J., C. Szabo, and C. Thiemermann. 1995. Isothioureas: Potent inhibitors of nitric oxide synthases with variable isoform selectivity. Br. J. Pharmacol. 114:510-516.

Szerszen, J.B., K. Szczyglowski, and R.S. Bandurski. 1994. iaglu, a gene from Zea mays involved in conjugation of growth hormone indole-3-acetic acid. Science 265:1699-1701.

Ueda, J., K. Miyamoto, and M. Hashimoto. 1996. Jasmonates promote abscission in bean petiole explants: Its relationship to the metabolism of cell wall polysaccharides and cellulase activity. J. Plant Growth Regul. 15:189-195.

Wilson, W.C., D.S. Kenney, and R.E. Holm. 1977. The Florida Department of Citrus cooperative screening program for citrus. Proc. Intl. Soc. Citricult. 2:692-696.

\title{
A Breeder's Perspective on the Use of Molecular Techniques for Improving Fruit Quality
}

\author{
J.W. Scott \\ University of Florida, IFAS, Gulf Coast Research and Education Center, 5007 60th Street East, \\ Bradenton, FL 34203
}

\begin{abstract}
Additional index words. biotechnology, crop improvement, cultivar, flavor, Lycopersicon esculentum, plant breeding, quantitative inheritance, tomato
\end{abstract}

Crop improvement is measured by new cultivars with improved yield, pest resistance, and/or product quality. It is not easy to develop a cultivar that is commercially successful for a long period of time. Of the many cultivars that are released, only a small percentage are successful as measured by large market share over a number of years. The difficulty involved in developing successful cultivars is probably underappreciated by many outside of plant breeding and even by some plant breeder/geneticists not engaged in finished cultivar development. This is an important point for those engaged in biotechnology. Engineered genes should be inserted into a successful cultivar in order to accurately define and maximize their impact. Historically, it is rare that the impact of a new cultivar is so great that existing cultivars are rendered obsolete and that newly available traits become a requirement of all future cultivars. Occasionally, a cultivar is released that is so good that it is grown on major acreages for decades, with a prime example being the 'Russet Burbank' potato. More often, improvements are of a minor nature and the successful new cultivar will be grown on lesser acreages and/or for a shorter time period before being replaced. However, most cultivar releases do not work out as planned and fail to be widely grown at all. Although these cultivar releases may have some improvements, they usually have an unanticipated weakness that limits their acceptance in the marketplace. Sometimes lack of acceptance is a marketing problem. Regardless, even unsuccessful releases were generally deemed worthy of release by their breeders and represent some of the best germplasm in a given breeding program. It can be concluded that developing a commercially successful cultivar is a difficult task that requires patience and hard work. The value of the background gene combinations required for a successful

Received for publication 29 Nov. 2001. Accepted for publication 30 Nov. 2001. Florida Agricultural Experiment Station Journal Series No. R-08490. cultivar should not be underestimated by anyone who hopes to market a new improved cultivar by conventional breeding or a biotechnological approach.

The term biotechnology is a broad term encompassing a wide range of science. For plant improvement it could include molecular markers linked to genes of interest or it could involve plant transformation. For this paper the focus will be on plant transformation where genes are modified or transferred by molecular means. Biotechnological advances hold promise as a means to solve problems that are intractable by traditional plant breeding methods and provide tools that are of potential benefit for crop improvement. With the above discussion on cultivars in mind, will the biotechnological improvements have major or minor impact? This depends on the improvements that are forthcoming and will need to be measured on a case-by-case basis, just as with new conventionally bred cultivars.

Many in the scientific community certainly have been enamored with the promise of biotechnology. Whereas no one could dispute the tremendous advances in basic plant science that have been made possible by biotechnology, the impact is not as clear when it comes to plant improvement. Over the last two decades, there have been many claims made for biotechnological "silver bullets" that will revolutionize the kinds of cultivars that are grown for a given crop. Perhaps this is due to the expense of biotechnological research. Why invest large sums of money for a less than monumental improvement? Today, there is a better understanding of the interface between biotechnology and plant breeding. Unlike the 1980 s, there are few that still believe that biotechnology will make plant breeders obsolete. Biotechnological impacts on crop improvement have been large and small just as with conventional breeding. As with the rest of science, only a small minority of hypotheses result in profound breakthroughs. I surmise that, in general, plant breeders welcome the new biotechnological tools, but do not care for the hype that too often accompanies (some of) them. Let's look at the present situation regarding commercial biotechnological crop improvement. 